\title{
CRAYFISH PREDATION EXPERIMENTS ON THE INTRODUCED ZEBRA MUSSEL, DREISSENA POLYMORPHA, IN IRELAND, AND THEIR POTENTIAL FOR BIOCONTROL.
}

\author{
J.D. REYNOLDS, R. DONOHOE
}

Department of Zoology, University of Dublin, Trinity College, DUBLIN 2, Ireland. E-mail : jrynolds@tcd.ie

\begin{abstract}
The zebra mussel Dreissena polymorpha, native to the Aralo-Caspian region, has spread across Europe in the last 180 years. Although it reached England in 1820, it only arrived in Ireland in around 1995, probably attached to the hull of pleasure boats, and since then has spread through the lowland Shannon and Erne systems, which are linked by canal. While White-clawed crayfish Austropotamobius pallipes (Lereboullet) occur in these systems, Dreissena has not yet colonized sites with large crayfish populations. In laboratory experiments crayfish of both sexes ranging in size from 32-48 $\mathrm{mm}$ carapace length $(\mathrm{CL})$ were offered zebra mussels in 7 size classes spanning a range from 3-17 mm total length. Crayfish fed most on small mussels, although there was some correlation between size of crayfish and largest mussels attacked. When eaten mussels were not replaced, crayfish shifted to larger sizes. In the presence of alternative prey, experienced crayfish ate mussels and alternative foods in similar amounts while those who had never encountered zebra mussels nearly always chose the alternative foods first. The possibility of crayfish exerting significant controlling impacts on expanding mussel populations is discussed.
\end{abstract}

Key-words : invasive species, Dreissena, crayfish predation, biocontrol.

\section{PRÉDATION EXPÉRIMENTALE DE LA MOULE EXOTIQUE DREISSENA POL YMORPHA PAR LES ÉCREVISSES EN IRLANDE, ET LEURS POTENTIALITÉS POUR UN CONTRÔLE BIOLOGIQUE.}

\section{RÉSUMÉ}

La moule zébrée, Dreissena polymorpha, native dans la région Aralo-Caspian, est disséminée à travers l'Europe depuis 180 ans. Bien qu'elle ait atteint l'Angleterre en 1820, cette espèce, probablement fixée à la coque des bateaux de plaisance, ne fut signalée en Irlande qu'en 1995 et, depuis, a envahi tout le bassin inférieur du Shannon ainsi que celui de l'Erne, ces bassins étant reliés par un canal. Dreissena n'a pas encore colonisé des sites hébergeant de belles populations d'écrevisses à pattes blanches Austropotamobius pallipes (Lereboullet). En laboratoire, des expériences ont consisté à offrir Dreissena selon 7 classes de taille (longueur totale de 3 à $17 \mathrm{~mm}$ ) à des écrevisses des deux sexes et ayant une longueur totale de carapace $(C L)$ de 32 à $48 \mathrm{~mm}$. Les 
écrevisses se nourrissent des petites moules, bien qu'il y ait une corrélation entre la taille des écrevisses et les plus grandes moules attaquées. Quand les moules consommées ne sont pas remplacées, les écrevisses vont s'attaquer à des moules de taille supérieure. En présence de proies alternatives, les écrevisses consomment les moules et les autres proies en quantité similaires alors que celles qui n'avaient jamais rencontré de moules auparavant vont toujours choisir en premier les autres nourritures proposées. L'impact possible de la prédation de Dreissena par les écrevisses est discuté en ce qui concerne le contrôle de cette espèce invasive.

Mots-clés : espèce invasive, Dreissena, prédation par les écrevisses, contrôle biologique.

\section{INTRODUCTION}

The Zebra mussel Dreissena polymorpha (Pallas 1771) is a freshwater, filter feeding bivalve mollusc native to the rivers flowing into the Black and Caspian Seas. This species has been introduced successfully to several continents through agencies such as ballast water, boat hulls, fishing equipment, aquarium dumping, and perhaps by waterfowl, although JOHNSON and CARLTON (1996) found this last method of dispersal to be unlikely. The main means of continental spread has been through canals, which aid the dispersion of veliger larvae from one catchment to another. The use of boats and barges along these man-made waterways has also provided an effective means for secondary settlement and translocation of adults. The zebra mussels' high reproductive output, filtering capability and their seasonal production of free swimming veliger larvae which will attach to hard substrates, have enabled Dreissena to invade an unexploited niche in freshwater systems and has caused much disruption both economically and ecologically around the world. Once established, zebra mussels have proven nearly impossible to remove. Their control is therefore of considerable interest.

Dreissena polymorpha appeared in London Docks in the 1820s (MORTON, 1969), perhaps with cargo from the Baltic Sea. It spread rapidly along canals and rivers and by 1850, it was widespread in southern England ; a distribution which is essentially unchanged today (KINSELBACH, 1992). Zebra mussels invaded the North American Great Lakes around 1986 (HEBERT et al., 1989). Here, unlike in Britain where Dreissena has had minimal industrial impact, clogging of cooling-water intakes is a major problem in the US.

In Ireland, the mussel was first observed and identified as $D$. polymorpha in 1997 in the lower River Shannon (Mc CARTHY and FITZGERALD, 1997). It was probably introduced about 1994 on leisure craft brought in from Britain (MINCHIN and MORIARTY, 1998) (Figure 1). The Shannon and Erne systems, linked by canal, have been successfully developed for cruising, and zebra mussels are now present in both, as are crayfish. To date, there are no indications of serious economic disruption by zebra mussels in Ireland. 


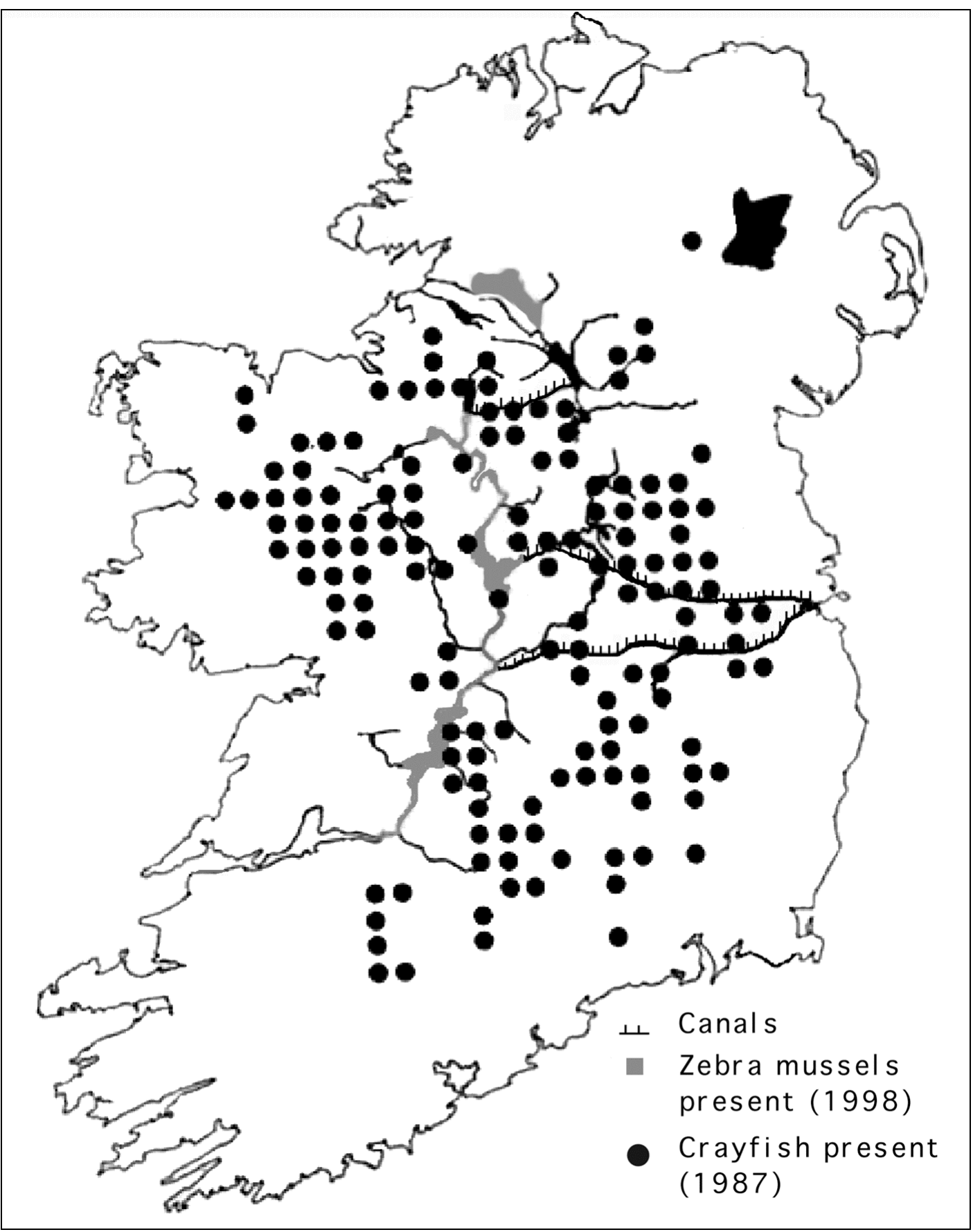

Figure 1

Recent distribution maps of Austropotamobius pallipes (1987) and Dreissena polymorpha (1998) in Ireland (after LUCEY and MC GARRIGLE, 1987 ; MINCHIN and MORIARTY, 1998).

Figure 1

Carte récente de la distribution de Austropotamobius pallipes (1987) et de Dreissena polymorpha (1998) en Irlande (d'après LUCEY et MC GARRIGLE, 1987 ; MINCHIN et MORIARTY, 1998). 


\section{Ecological impacts affecting crayfish}

Ecological impacts of introduced zebra mussels may be long-term (MAC ISAAC, 1996). One such is their infestation of hard-shelled freshwater invertebrates, principally unionid bivalves (SCHLOESSER et al., 1996), although freshwater crayfish may also become infested (STUCKI, 1999 ; BRAZNER and JENSEN, 2000), especially older crayfish which moult infrequently.

System level impacts involve shifts from planktonic to benthic productivity (e.g. DERMOTT and KEREC, 1997, for the American Great Lakes), which may be advantageous to crayfish with their wide feeding range. Increasing eutrophication and lowered water quality have been a feature of the Shannon and Erne systems (LUCEY et al., 1999). Reduced phosphate levels have been noted recently in the Shannon following phosphate stripping at sewage works, but the feeding activity of Dreissena may also have played a part. Positive impacts on crayfish might relate to pseudofaecal stimulation of the benthos and opportunities for direct predation.

\section{Predation on zebra mussels}

Predation on Dreissena, from trochophore and veliger stages to adults, may involve crayfish, copepods (LIEBIG and VANDERPLEOG, 1995), also ducks and a number of fish species such as eels and roach. Other predators of zebra mussels include coelenterates, annelids, turtles and rodents (MOLLOY et al., 1997). In Polish lakes roach, with their strong pharyngeal denticles, feed almost exclusively (95-100\%) on zebra mussels (MACKIE and SCHLOESSER, 1996) and their predation impact may be significant. Diving ducks may also consume zebra mussels in huge numbers, although they have had no measurable impact on mussel numbers either in Lake Erie (HAMILTON et al., 1994) or in Europe (HAMILTON et al., 1994 ; de KNOCK and BOWMER, 1993).

Although decapod crustaceans have been shown to feed on zebra mussels in laboratory and field studies, these predators mainly select zebra mussels of small to medium size classes. Marine crabs may be effective predators on adult zebra mussels where both coexist in estuaries (MOLLOY et al., 1994 ; BOLES and LIPCIUS, 1997).

Predation by Orconectes spp. crayfish on the introduced zebra mussel has been studied both in North America and in Europe (MOLLOY et al., 1997). In North America, LOVE and SAVINO (1993) showed Orconectes virilis to be effective predators on zebra mussels, but noted that they show preference for other, more easily manipulated foods, if available. In Europe, the introduced Orconectes limosus has also been shown to be an effective predator of zebra mussels. PIESIK (1974) calculated that this crayfish could take up to 100 small $(1-5 \mathrm{~mm})$ zebra mussels daily in the river Odra in central Europe, although LOVE and SAVINO (1993) suggest this may be affected by the lack of other available food sources.

MARTIN and CORKUM (1994) found that Orconectes virilis ate almost exclusively zebra mussels $\leq 8 \mathrm{~mm}$ long but the per capita mussel consumption decreased at crayfish densities greater than four per $\mathrm{m}^{2}$. This would seem to indicate that measures to artificially introduce large stocks of crayfish into an area in an attempt to control zebra mussels would be ineffective. MAC ISAAC (1994) showed that Orconectes propinquus displayed a strong numerical preference for small (3-5 mm) zebra mussels. However, in this laboratory-based study, larger zebra mussels were in fact attacked more often than smaller individuals, the lower predation rates merely representing rejection after unsuccessful predation attempts. Survival of zebra mussels also increased when the crayfish were offered alternative macrophyte foods. 
The threatened White-clawed crayfish, Austropotamobius pallipes (Lereboullet) is now chiefly restricted to headwater streams in most of its Atlantic distribution. In Ireland it is still fairly widely distributed, but is rarely found in lakes of larger than 1000 ha or in large rivers (MORIARTY, 1973), where zebra mussels are at present most frequent (Figure 1). However, it is likely that zebra mussels will soon spread into Irish crayfish strongholds. This paper examines the results of preliminary laboratory studies into the predation of Austropotamobius pallipes on the introduced zebra mussel, Dreissena polymorpha and suggests ecological outcomes.

\section{MATERIAL AND METHODS}

Zebra mussels were obtained from the Shannon system at Dromineer Bay, Lough Derg, and crayfish under licence from wild stocks in the Grand Canal near Dublin, between December 2000 and February 2001. This canal links Dublin with the Shannon system north of Lough Derg. Crayfish were measured (carapace length to the nearest $1 \mathrm{~mm}$ ) and held in separate compartments, three to a 5 litre plastic tank, with canal water at $14{ }^{\circ} \mathrm{C}$.

17 adult crayfish of both sexes ranging in size from $32-48 \mathrm{~mm}$ carapace length $(\mathrm{CL})$ were used in feeding experiments involving different sized zebra mussels ranging from 3$17 \mathrm{~mm}$ total length, in $2 \mathrm{~mm}$ size-classes. After crayfish were acclimated to $14 \pm 1^{\circ} \mathrm{C}$ they were starved for $24 \mathrm{~h}$ and then presented with seven mussels, one each from different shell-length size classes (class 1, 3-4.9 $\mathrm{mm}$; to class 7, 15-16.9 mm).

Crayfish were checked every day and any eaten mussels recorded and replaced by individuals of the same size. All feeding attempts on mussels (shell chipped or damaged, or observed manipulation) were noted. Experiments were run for 9 days, to see if either starvation or learning increased the amount of feeding over the time period. In a second series of experiments with seven male crayfish, eaten mussels were not replaced. Data were log-transformed prior to a t-test where alpha was set to 0.05 . Naive crayfish were also compared to experienced crayfish, familiar with zebra mussels as food, when alternative foods were introduced.

\section{RESULTS}

\section{Size classes consumed by crayfish}

Most crayfish fed on mussels less than $11 \mathrm{~mm}$ total length with mussels $3-7 \mathrm{~mm}$ (size classes 1 and 2) being consumed in the highest numbers (Table 1). Larger crayfish consumed more mussels, generally from a wider size-range, than did smaller crayfish.

Table 1 also shows great individual variability in numbers eaten, e.g. the male crayfish ate between 3 and 51 mussels over 9 days. There is also a difference in consumption rates with size of crayfish and with sex. The four larger males, with a mean $\mathrm{CL}$ of $43.8 \mathrm{~mm}$, ate a mean of 36.5 mussels of various sizes. Seven smaller males (mean CL 33.8) ate a mean of 16.4 mussels, while five smaller females (mean CL 35.6) ate a mean of only 8.0 mussels. Ovigerous and non-ovigerous females consumed on average $50-80 \%$ less than their male counterparts of similar carapace length. Males also ate larger mussels than females (large males ate mussels of a mean size-class of $5(11-12.9 \mathrm{~mm})$; small males 2 (5-6.9 mm) and females just $1(3-4.9 \mathrm{~mm})$. 


\section{Table 1}

Summary of feeding experiments involving the presentation of 7 size classes of Dreissena polymorpha to 17 Austropotamobius pallipes, both males and females. Results show the numbers consumed over a series of 9 tests.

\section{Tableau I}

Résumé des expérimentations consistant en la présentation de Dreissena polymorpha (selon 7 classes de taille) à 17 Austropotamobius pallipes. Les résultats traduisent le nombre de moules consommées pour une série de 9 tests impliquant à la fois des mâles et des femelles.

\begin{tabular}{|c|c|c|c|c|c|c|c|}
\hline $\begin{array}{c}\text { Carapace Length } \\
(\mathbf{m m})\end{array}$ & \multicolumn{7}{|c|}{ Total numbers eaten } \\
\hline \multirow{3}{*}{ Females } & \multicolumn{7}{|c|}{ Zebra mussel size class } \\
\cline { 2 - 8 } 32.9 & $\mathbf{1}$ & $\mathbf{2}$ & $\mathbf{3}$ & $\mathbf{4}$ & $\mathbf{5}$ & $\mathbf{6}$ & $\mathbf{7}$ \\
\cline { 2 - 7 } 33.3 & 1 & 0 & 0 & 0 & 0 & 0 & 0 \\
36.4 & 4 & 5 & 2 & 0 & 0 & 0 & 0 \\
37.4 & 7 & 3 & 3 & 0 & 0 & 0 & 0 \\
38 & 3 & 4 & 3 & 0 & 0 & 0 & 0 \\
Smaller males & 3 & 2 & 0 & 0 & 0 & 0 & 0 \\
33.75 & & & & & & & \\
33.8 & 6 & 6 & 1 & 0 & 0 & 0 & 0 \\
33.9 & 8 & 6 & 3 & 0 & 0 & 0 & 0 \\
34.2 & - & - & - & - & - & - & - \\
34.3 & 1 & 2 & 0 & 0 & 0 & 0 & 0 \\
36.3 & 9 & 9 & 8 & 5 & 3 & 0 & 0 \\
36.3 & - & - & - & - & - & - & - \\
Larger males & & & & & & & \\
40.5 & 5 & 5 & 3 & 0 & 0 & 0 & 0 \\
41.5 & 8 & 6 & 6 & 6 & 3 & 2 & 3 \\
45.8 & 9 & 8 & 9 & 9 & 8 & 6 & 2 \\
47.5 & 9 & 9 & 8 & 8 & 8 & 4 & 2 \\
48.6 & - & - & - & - & - & - & - \\
\hline
\end{tabular}

Overall there was a moderate correlation ( $R$ squared $=53.6 \%, p=0.0013$ ) between crayfish carapace length and maximum mussel length consumed. When the data were separated by sex a stronger correlation is seen for males $(y=0.608 x-11.339$, $\mathrm{R}$ squared $=61.5 \%, p=0.0025$ ) (Figure 2 ) than for females. 


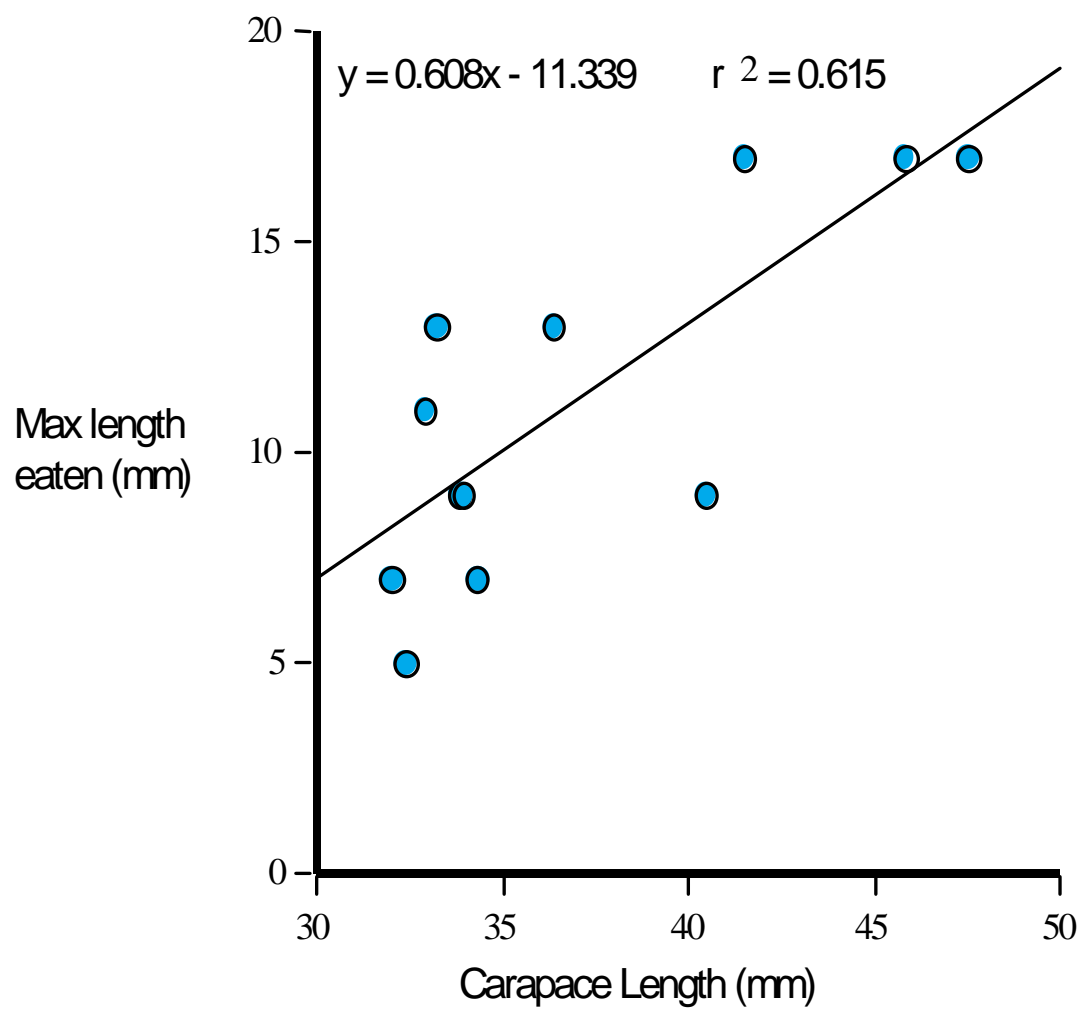

Figure 2

Maximum length of zebra mussels consumed by male crayfish $(n=11)$.

\section{Figure 2}

Taille maximale des moules consommées par des écrevisses mâles $(n=11)$.

\section{Maximum number of mussels consumed}

The maximum number of size class 2 zebra mussels $(5-7 \mathrm{~mm})$ consumed in a $24 \mathrm{~h}$ period by a selection of crayfish shows a close correlation with crayfish carapace length ( $\mathrm{R}$ squared $=62.0 \%, p=0.0068$ ). Again, removing the females from the data showed a more significant relationship $(R$ squared $=82.1 \%$, slope $=0.682, p=0.0049)$.

\section{Changes in feeding patterns following starvation and non-replacement of prey}

Feeding test results were fairly consistent when prey was in plentiful supply. However, following starvation for $24 \mathrm{~h}$ and non-replacement of prey, crayfish switched to feeding on significantly larger zebra mussels ( $p=0.045,6 \mathrm{df}$ for maximum size values) (Table II). 


\section{Table II}

Largest size class of mussels taken by 7 male crayfish before and after $24 \mathrm{~h}$ starvation, with non-replacement of eaten mussels.

\section{Tableau II}

Classe de taille la plus grande consommée par sept écrevisses mâles avant et après $24 \mathrm{~h}$ de jeûn et aucun remplacement des moules consommées.

\begin{tabular}{|c|c|c|}
\hline $\begin{array}{c}\text { Carapace } \\
\text { length }(\mathrm{mm})\end{array}$ & $\begin{array}{c}\text { Max size class } \\
\text { before }\end{array}$ & Max size class after \\
\hline 32 & 2 & 2 \\
\hline 32.9 & 2 & 4 \\
\hline 33.8 & 2 & 3 \\
\hline 33.9 & 2 & 3 \\
\hline 34.3 & 1 & 1 \\
\hline 36.3 & 5 & 7 \\
\hline 41.5 & 7 & 7 \\
\hline \multicolumn{2}{|c}{} \\
\hline
\end{tabular}

\section{Feeding patterns in the presence of alternative foods}

Figure 3 shows the mean response of crayfish to alternative plant and animal food sources when given in the presence of $D$. polymorpha. Results seem to show that crayfish size may be an important factor in determining what is eaten. When alternative foods were introduced, experienced crayfish ate zebra mussels and alternative foods in similar amounts while those who had never encountered zebra mussels nearly always chose the alternative foods first.

\section{Means for food preference experiments}

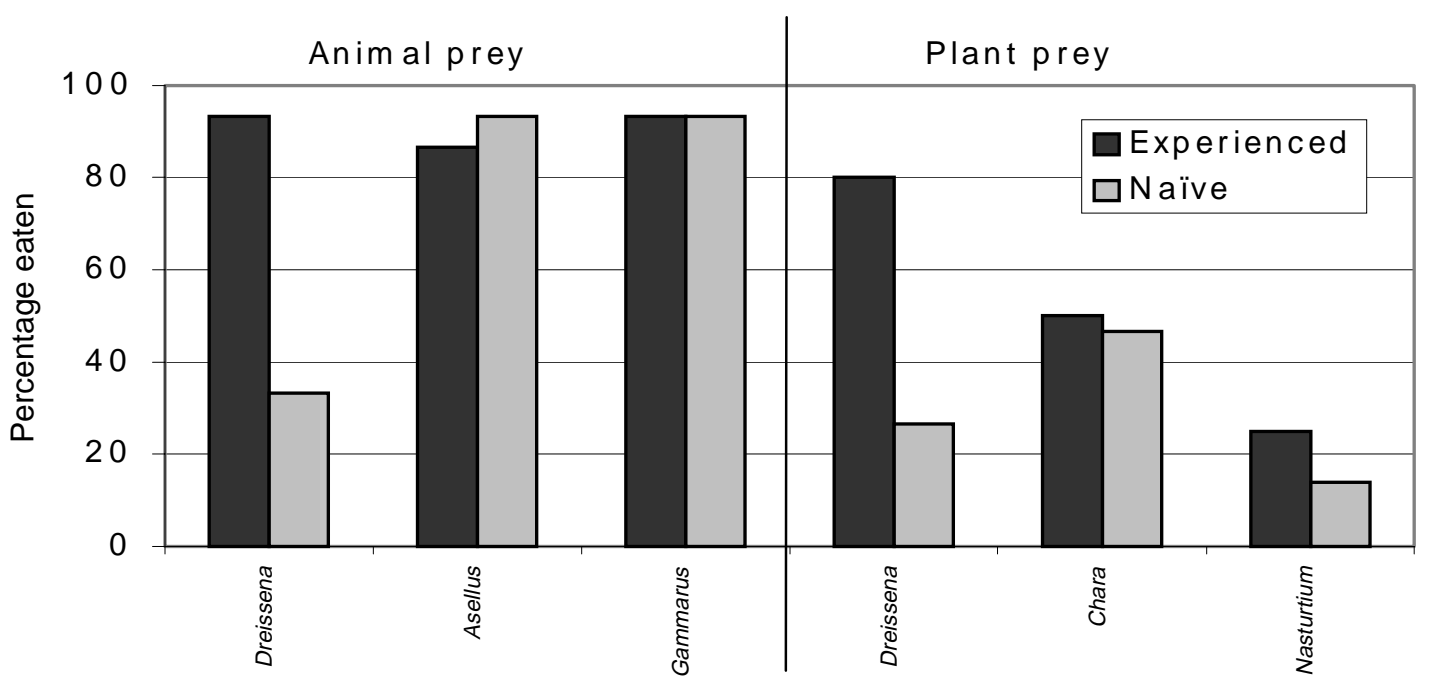

Figure 3

Feeding response of 3 naive and 3 experienced crayfish to two animal and two plant alternative foods offered at the same time as zebra mussels.

\section{Figure 3}

Réponses observées en ce qui concerne la consommation par 3 écrevisses "naïves " et 3 "expérimentées " après présentation de deux autres aliments animaux ou de deux aliments végétaux en même temps que des moules. 


\section{Opening techniques}

Crayfish feeding behaviour was observed and crushed Dreissena shells collected from the crayfish aquaria were examined. Mussels were picked up by the pereiopods and manipulated by the mouthparts before being crushed by the mandibles. The smaller mussels seemed to be crushed outright. Larger ones, on the other hand, were mainly opened first by edge chipping, followed by prying. No definite threshold size of mussels was observed that corresponded to a particular opening technique.

\section{DISCUSSION}

Most crayfish are omnivorous benthic feeders taking a variety of both animal and plant material (LOVE and SAVINO, 1993 ; MATTHEWS et al., 1993). Some are known to be keystone predators in aquatic systems (CHAMBERS et al., 1990 ; LODGE et al., 1994 ; NYSTROM et al., 1996 ; STEWART et al., 1996). Significant impacts on the benthic community have been demonstrated in both laboratory and field studies (HANSON et al., 1990 ; MATTHEWS et al., 1993).

\section{Feeding patterns of crayfish on zebra mussels.}

It has been shown that some Orconectes species will feed on zebra mussels, but the potential of astacids and, in particular, of Austropotamobius pallipes to control zebra mussels has not been assessed. In tests white-clawed crayfish fed predominantly on the smaller size classes of zebra mussels, with a tendency for larger crayfish to feed on larger zebra mussels. However, when consumed mussels were not replaced, some individual crayfish displayed a size shift in their feeding pattern, successfully feeding on mussels up to two size-classes $(4 \mathrm{~mm})$ larger than the largest ones eaten previously. MAC ISAAC (1994) showed that Orconectes propinquus attacked all sizes of mussel, but could only open the smaller ones. There thus appears to be a maximum size of mussel that an individual crayfish can consume ; in the case of large $A$. pallipes this may be around $17 \mathrm{~mm}$ (size-class 7). Large crayfish consumed larger numbers of zebra mussels than did smaller ones in tests. Since starvation period was standardised this could be related to stomach size, or to handling time needed for smaller crayfish to open the bivalves.

Most decapod species forage on mainly small-sized molluscan prey (JUANES, 1992 ; SEED and HUGHES, 1995 ; ELNER and HUGHES, 1978 ; JUBB et al., 1983 ; BURCH and SEED, 2000) even though they are capable of consuming bivalves of a much greater size. One reason for this apparent small size selectivity in crustacean predators is to maximise energy (ELNER and HUGHES, 1978). Mussel shell strength increases with increasing size, leading to a lower cost-benefit for the predator. Small mussels on the other hand are relatively easy to open, but offer a lower calorific value. At an intermediate size, the net energy intake per unit foraging time should be maximised. The low energy content of small $(5 \mathrm{~mm})$ zebra mussels is about $1 \%$ of that for larger $(25 \mathrm{~mm})$ zebra mussels (DROULANS and WOUTERS, 1988). Nonetheless, A. pallipes preferred the smaller mussels in experiments, unless these were no longer available.

MICHELI (1995) showed that starved blue crabs (Callinectes sapidus) initially preferred small clams, but training experiments suggested that crabs might modify their preferences through experience. The most important factor seemed to be shell strength, rather than shell size, as a condition for optimal foraging behaviour. The preference in the wild for smaller clams therefore seems to be a learned behaviour rather than an in-built selective pattern for feeding.

Female crayfish showed a different pattern from males. Neither ovigerous females nor those that had lost their eggs (1-3 eggs remaining when first caught) responded to 
many of the feeding trials, including those involving alternative prey. This is most likely due to physiological changes and a suppression of diet occurring after oviposition. In general, ovigerous females are less trappable than males (MATTHEWS and REYNOLDS, 1995), and consisted of only $23 \%$ of the total catch for these experiments.

When crayfish that had never encountered zebra mussels before were presented with alternative foods in the presence of Dreissena, most showed a strong preference for the other foods. This finding could be explained by increased encounter rates of the mobile animal prey, but macrophyte test results were less clearly explainable and may represent a true preference. Thus, a proliferation of zebra mussels in a crayfish habitat will not necessarily result in a switch to them as food.

\section{Mollusc opening techniques in decapod predators}

In present tests, crayfish were seen to use their mandibles to chip or crush shells. Many groups of decapod crustaceans have specialised, dimorphic chelae to break open hard prey items (SHOUP, 1968 ; ELNER and CAMPBELL, 1981 ; SEED and HUGHES, 1995). Different shell opening tactics are used when presented with different size classes of bivalves. Most larger crabs and lobsters chiefly crush their prey, while smaller, more dextrous decapods use perimeter tactics (described as prying, edge chipping, boring and gape entry) to open marine mussels (MOODY and STENECK, 1993). BURCH and SEED (2000) found that Carcinus maenas mainly used perimeter tactics on larger marine mussels Mytilus edulis.

The ability of decapod crustaceans to affect local population densities of bivalve prey is well documented (SEED, 1993 ; ENRIGHT et al., 1993). VAN DER VEER et al. (1998) demonstrated predation on bivalve spat (or post-veliger mussels) by brown shrimps, Crangon crangon and shore crabs in the Dutch Wadden Sea. Although juvenile crayfish can filter-feed (HOLDICH and LOWERY, 1988), it has yet to be demonstrated if zebra mussel spat would succumb to similar crayfish predation.

It is not clear if crab or crayfish predation could have significant controlling impacts on the expanding populations of zebra mussels, because of high levels of recruitment and immigration from other areas. We would thus expect to see only local and temporary reductions or extinctions. Freshwater crayfish are widespread in lowland Ireland (REYNOLDS, 1982 ; LUCEY and MC GARRIGLE, 1987 ; see Figure 1). Best populations occur in tributary streams and small lakes, while Dreissena is chiefly transported by leisure craft operating on the large rivers and canals. Dreissena may soon overlap with good stocks of Austropotamobius in the Grand Canal in Co. Dublin, and the upper lakes of the Erne System.

\section{CONCLUSION}

Dreissena polymorpha is an exotic bivalve species that has been shown to cause severe ecological changes in freshwater systems. Along with fish and diving ducks, decapod crustaceans (crayfish in particular) have been shown to be effective predators on mussels. With the continual spread of zebra mussels across the globe it appears that more study into natural control measures is needed. This should be through examination into the potential for native predator species to control Dreissena in areas under threat. 


\section{ACKNOWLEDGEMENTS}

We are grateful to Constanze O'Toole and Richard Hollingshead for kindly collecting zebra mussels and crayfish (under licence) respectively, to Alison Boyce for her help with statistics and figures,to Frank Jeal for advice on marine crab and mussel interactions, and to Catherine Souty-Grosset for kind assistance with the French text.

\section{REFERENCES}

BOLES L.C., LIPCIUS R.N., 1997. Potential for population regulation of the zebra mussel by finfish and the blue crab in North American estuaries. J. Shellfish. Res. 16 (1), 179-186.

BRAZNER J.C., JENSEN D.A., 2000. Zebra mussel (Dreissena polymorpha Pallas) colonisation of rusty crayfish (Orconectes rusticus Girard) in Green Bay, Lake Michigan. Am. Midl. Nat., 143 (1), 250-256.

BURCH A., SEED R., 2000. Foraging behaviour of Carcinus maenas on Mytilus edulis : the importance of prey presentation. J. Mar. Biol. Ass. U.K., 80, 799-810.

CHAMBERS P.A., HANSON J.M., BURKE J.M., PREPAS E., 1990. The impact of the crayfish Orconectes virilis on aquatic macrophytes. Freshwater Biol., 24 (1), 81-91.

DE KNOCK W.C., BOWMER C.T., 1993. Bioaccumulation, biological effects and food chain transfer of contaminants in the zebra mussel (Dreissena polymorpha). In : NALEPA T.F. and SCHLOESSER D.W. (Eds.)., Zebra mussels : Biology, impacts and control, 503-533. Lewis Publishers, Boca Raton, Florida.

DERMOTT R., KEREC D., 1997. Changes to the deepwater benthos of eastern Lake Erie since the invasion of Dreissena : 1979-1993. Canadian J. Fisheries \& Aquatic Science, 54, 922-930.

DROULANS D., WOUTERS R., 1988. Density, growth and calorific value of Dreissena polymorpha (Mollusca : Bivalvia) in a pond created by sand extraction, and its importance as food for fish. Ann/s. Soc. R. Zool. Belg., 118, 51-60.

ELNER R.W., CAMPBELL A., 1981. Force, function and mechanical advantage in the chelae of the American lobster Homarus americanus (Decapoda : Crustacea). J. Zool., Lond., 193, 269-286.

ELNER R.W., HUGHES R.N., 1978. Energy maximisation in the diets of the shore crab, Carcinus maenas. J. Anim. Ecol., 47 (1), 103-116.

ENRIGHT C.T., ELNER R.W., GRISWOLD A., BORGESE E.M., 1993. Evaluation of crabs as control agents for biofouling in suspended culture of European oysters. World Aquaculture, 24 (4), 49-51.

HAMILTON D.J., ANKNEY C.D., BAILEY R.C., 1994. Predation of zebra mussels by diving ducks : an exclosure study. Ecology, 75 (2), 521-531.

HANSON J.M., CHAMBERS P.A., PREPAS E.E., 1990. Selective foraging by the crayfish Orconectes virilis and its impact on macroinvertebrates. Freshwater Biol., 24, 69-80.

HEBERT P.D.N., MUNCASTER B.W., MACKIE G.L., 1989. Ecological and genetic studies on Dreissena polymorpha (Pallas) : a new mollusc in the Great Lakes. Can. J. Fish. Aquat. Sci., 46, 1587-1591.

HOLDICH D.M., LOWERY R.S., 1988. Freshwater crayfish : biology management and exploitation. Croom Helm, London, 498 p.

JOHNSON L.E., CARLTON J.T., 1996. Post-establishment spread in large-scale invasions: dispersal mechanisms of the zebra mussel, Dreissena polymorpha. Ecology, 77 (6), 1686-1690.

JUANES F., 1992. Why do decapod crustaceans prefer small-sized molluscan prey ? Mar. Ecol. Prog. Ser., 87, 239-249.

JUBB C.A., HUGHES R.N., AP RHEINLIT T., 1983. Behavioural mechanisms of sizeselection by crabs, Carcinus maenas (L.) feeding on mussels, Mytilus edulis (L). J. Exp. Mar. Biol. Ecol., 66, 81-87. 
KINSELBACH R., 1992. The main features of the phylogeny and dispersal of the zebra mussel Dreissena polymorpha. 1-17. In : NEUMANN D. and JENNER H.A. (Eds.). The zebra mussel Dreissena polymorpha : ecology, biological monitoring and first applications in water quality management. Fisher Verlag, Stuttgart.

LIEBIG J.R., VANDERPLOEG H.A., 1995. Vulnerability of Dreissena polymorpha larvae to predation by Great Lakes calanoid copepods : the importance of the bivalve shell. J. Great Lakes Res., 21 (3), 353-358.

LODGE D.M., KERSHNER M.W., ALOI J.E., COVICH A.P., 1994. Effects of an omnivorous crayfish (Orconectes rusticus) on a freshwater littoral food web. Ecology, 75, 1265-1281.

LOVE J., SAVINO J.F., 1993. Crayfish (Orconectes virilis) predation on zebra mussels (Dreissena polymorpha). J. Freshwater Ecol., 8, 253-259.

LUCEY J., MC GARRIGLE M.L., 1987. The distribution of the freshwater crayfish in Ireland. Irish Fisheries Investigations, 29A, 1-13.

LUCEY J., BOWMAN J.J., CLABBEY K.J., CUNNINGHAM P., LEHANE M., MAC CARTHAIGH M., MC GARRIGLE M.L., TONER P.F., 1999. Water quality in Ireland 1995-1997. Environmental Protection Agency, Wexford, Ireland, $122 \mathrm{p}$.

MAC ISAAC H.J., 1994. Size-selective predation on zebra mussels (Dreissena polymorpha) by crayfish (Orconectes propinquus). J. North. Am. Benthol. Soc., 13, 206-216.

MAC ISAAC H.J., 1996. Potential abiotic and biotic impacts of zebra mussels on the inland waters of North America. Amer. Zool., 36, 287-299.

MACKIE G.L., SCHLOESSER D.W., 1996. Comparative Biology of Zebra Mussels in Europe and North America : An Overview. Amer. Zool., 36, 244-258.

MARTIN G.W., CORKUM L.D., 1994. Predation of zebra mussels by crayfish. Can. J. Zool., 72, 1876-1871.

MATTHEWS M., REYNOLDS J. D., 1995. A population study of the white-clawed crayfish Austropotamobius pallipes (Lereboullet) in an Irish reservoir. Biology \& Environment, 95B, 99-109.

MATTHEWS M., REYNOLDS J.D., KEATINGE M.J., 1993. Macrophyte reduction and benthic community alteration by the crayfish Austropotamobius pallipes (Lereboullet). Freshwater Crayfish, 9, 289-299.

MC CARTHY T.K., FITZGERALD J., 1997. The occurrence of the Zebra mussel Dreissena polymorpha (Pallas, 1771), an introduced biofouling freshwater bivalve in Ireland. Irish Nats. J., 25, 413-416.

MICHELI F., 1995. Behavioural plasticity in prey-size selectivity of the blue crab Callinectes sapidus feeding on bivalve prey. J. Anim. Ecol., 64 (1), 63-74.

MINCHIN D., MORIARTY C., 1998. Zebra mussels in Ireland. Fisheries Leaflet 177, 11 p., Marine Institute, Ireland.

MOLLOY D.P., KARATAYEV A.Y., BURAKLOVA L.E., KURANDINA D.P., LAURELLE F., 1997. Natural enemies of zebra mussels, predators, parasites and ecological competitors. Rev. Fish. Sci., 5, 27-97.

MOLLOY D.P., POWELL J., AMBROSE P., 1994. Short-term reduction of adult zebra mussels (Dreissena polymorpha) in the Hudson river near Catskill, New York : An effect of juvenile blue crab (Callinectes sapidus) predation ? J. Shellfish. Res., 13 (2), 367-371.

MOODY K.E., STENECK R.S., 1993. Mechanism of predation among large decapod crustaceans of the Gulf of Maine Coast : Functional vs. phylogenetic patterns. J. Exp. Mar. Biol. Ecol., 168, 111-124.

MORIARTY C., 1973. A study of Austropotamobius pallipes in Ireland. Freshwater Crayfish, 1, 57-68.

MORTON B.S., 1969. Studies on the biology of Dreissena polymorpha Pall. I. General anatomy and morphology. Proc. Malac. Soc. Lond., 38, 301-321.

NYSTROM P., BRONMARK C., GRANELI W., 1996. Patterns in benthic food webs : a role for omnivorous crayfish? Freshwater Biol., 36, 631-646. 
PIESIK Z., 1974. The role of the crayfish Orconectes limosus (Raf.) in extinction of Dreissena polymorpha (Pall.) subsiding on steelon net. Pols. Arch. Hydrobiol., 21, 401-410.

REYNOLDS J.D., 1982. Notes on the distribution of the freshwater crayfish. Bull. Ir. Biogeog. Soc., 6, 18-24.

SCHLOESSER D.W., NALEPA T.F., MACKIE G.L., 1996. Zebra mussel infestation of unionid bivalves (Unionidae) in North America. Amer. Zool., 36, 300-310.

SEED R., 1993. Invertebrate predators and their role in structuring coastal and estuarine populations of filter feeding bivalves. NATO ASI (Advanced Science Institutes) Series. Series G Ecological Sciences, 33, 149-195.

SEED R., HUGHES R.N., 1995. Criteria for prey size-selection in molluscivorous crabs with contrasting claw morphologies. J. Exp. Mar. Biol. Ecol., 193 (1-2), 177-195

SHOUP J.B., 1968. Shell opening by crabs of the Genus Calappa. Science, 160, 887-888.

STEWART T.W, MINER J.G., LOWE R.L., 1996. Effects of crayfish on a benthic macroinvertebrate community in Western Lake Erie. Abstract from the sixth international zebra mussel and other aquatic nuisance species conference, Dearborn, Michigan. March 1996.

STUCKI T.P., 1999. Life cycles and life history of Astacus leptodactylus in Chalzensee Pond (Zurich) and Lake Ageri., Switzerland. Freshwater Crayfish, 12, 430-448.

VAN DER VEER H.W., FELLER R.J., WEBER A., WITTE J.I., 1998. Importance of predation by crustaceans upon bivalve spat in the intertidal zone of the Dutch Wadden Sea as revealed by immunological assays of gut contents. J. Exp. Mar. Biol. Ecol., 231 (1), 139-157. 
